\title{
Another invisible enemy indoors: COVID-19, human health, the home, and United States indoor air policy
}

\author{
Jamaji C. Nwanaji-Enwerem $\mathbb{1}^{1} \cdot$ Joseph G. Allen² Paloma I. Beamer $^{3}$
}

Received: 27 May 2020 / Accepted: 29 June 2020 / Published online: 8 July 2020

(c) Springer Nature America, Inc. 2020

\begin{abstract}
After the emergence of the respiratory virus SARS-CoV-2 (COVID-19), many exposure and environmental health scientists promptly recognized the potentially catastrophic public health ramifications of concurrent infectious and air pollutionmediated disease. Nevertheless, much of this attention has been focused on outdoor interactions. Each year, 3.8 million people worldwide prematurely die from illnesses attributable to indoor air. Hence, poor household indoor air quality is a long-standing public health issue with even greater relevance now that many individuals are spending more time at home. At present, the Environmental Protection Agency does not regulate indoor air, and state-level legislation has resulted in a patchwork of national coverage. Here, we describe common sources of indoor air pollution, the health impacts of indoor pollutants, and populations disparately impacted by COVID-19 and poor indoor air quality. Furthermore, we detail the need for better legislation that promotes the integrity of the indoor air environment, and what individuals can do to personally protect themselves as we await more comprehensive indoor air legislation.
\end{abstract}

Keywords COVID-19 $\cdot$ Indoor air pollution

Following the emergence of the novel respiratory virus SARS-CoV-2 (COVID-19), many environmental health experts quickly identified the potentially disastrous public health ramifications of concurrent infectious and air pollution-mediated disease [1]. However, much of this discussion has focused on the outdoors. Annually, 3.8 million people worldwide prematurely die from illnesses attributable to household air pollution [2]. In the United States, radon, a major indoor air pollutant, is the second leading cause of lung cancer and is responsible for 15,000-20,000 deaths each year [3]. Although stay-at-home orders and remote working/learning have increased the

Jamaji C. Nwanaji-Enwerem

jamaji_nwanaji-enwerem@hms.harvard.edu

1 Belfer Center for Science and International Affairs, Harvard Kennedy School of Government, Department of Environmental Health, Harvard T.H. Chan School of Public Health, and MD/PhD Program, Harvard Medical School, Boston, MA, USA

2 Department of Environmental Health, Harvard T.H. Chan School of Public Health, Boston, MA, USA

3 Department of Community, Environment, and Policy, Mel and Enid Zuckerman College of Public Health, University of Arizona, Tucson, AZ, USA relevance of home indoor exposures to all persons, there are still certain vulnerable populations that bear a disparate burden of avoiding the virus outdoors and being exposed to nontrivial pollutants indoors. These populations include children, the elderly, individuals with preexisting conditions, Native American tribal nations, and households of low socioeconomic status-particularly those in multifamily buildings [4-7]. To be explicit, this is not a call for ignoring social distancing and other public health orders. Rather, similar to efforts drawing attention to increases in domestic abuse and the mental health consequences of isolation $[8,9]$, it is an opportunity to name poor household indoor air quality as a long-standing public health issue with increased relevance during the present pandemic.

One common misconception is that the indoor air environment is simply a reflection of the outdoor milieu; however, this is not always the case. Outdoor air pollution penetrates indoors, and because Americans spend a majority of their times indoors ( $>90 \%)$, the majority of exposure to outdoor air pollution occurs indoors. Nevertheless, there are distinct, important sources of indoor air pollution [10]. Fireplaces, kitchens, furniture, wall insulation, and personal care products, are just some noteworthy sources of indoor pollutants. Household cleaning products are a particularly relevant source of indoor pollution at this juncture in time given that 
many people may be cleaning more frequently and with stronger disinfectants to reduce rates of viral infection. Furthermore, efforts to make homes airtight to improve energy efficiency have created buildings with reduced outdoor ventilation rates resulting in the buildup of indoor pollutants to harmful levels that would be otherwise unacceptable outdoors $[11,12]$. Importantly, the toxicity of indoor air extends beyond the health effects of individual pollutants. The reactive chemistry of pollutants can be an additional source of harmful indoor chemicals including secondary ozonides, oxygenated volatile organic compounds, and hydroxyl radicals [13]. Finally, the microbiota of the indoor environment is becoming an ever-more appreciated contributor to indoor air quality [14, 15]. Existing studies demonstrate that indoor air microbiomes are quite diverse, and can have meaningful impacts on human health [16]. Although individuals are primarily concerned with the burden of COVID-19 in their indoor air, aerosolized COVID-19 does not exist in isolation. Hence, recognition of all airborne microorganisms and how the indoor air microbiome may interact with many of the aforementioned chemical exposures is important for building a more comprehensive understanding of indoor air quality.

In contrast to the outdoors where federal mandates like the Clean Air Act of 1970 have been passed to maintain air quality, direct top-level legislation for indoor air quality has been lacking. The Environmental Protection Agency (EPA) Indoor Air Quality program was slated to be cut in the 2019 federal budget, and at present the EPA does not regulate indoor air [17]. Some may point to the U.S. Housing Act (1937), the Safe Water Drinking Act (1974), the Residential Lead Hazard Reduction Act (1992), and the updated Toxic Substances Control Act (TSCA) (2016) as examples of legislation addressing the indoor environment. However, these measures are indirect in that they limit the introduction of harmful substances that are brought indoors, but do not regulate the indoor environment itself. They have also demonstrated weaknesses in effectiveness. For instance, despite the TSCA, the EPA still identified the need to offer a final ruling, "that any discontinued uses of asbestos cannot reenter the marketplace without EPA review," in April of 2019 [18]. This ruling is particularly concerning as it opens the door for the EPA to reconsider uses of asbestos and could result in the reintroduction of asbestos to the marketplace. In lieu of federal indoor air mandates, some states have offered legislation to control the air in schools and other buildings. Still, efforts directed at private homes remain limited. Moreover, these state-level policies leave a patchwork of national coverage [19].

The existing discrepancy in the frameworks for regulating outdoor and indoor air can be partially explained by the perception of outdoor air as a shared public good, but indoor air as a discrete personal resource with non-communal impacts [20]. Yet, COVID-19 demonstrates how this logic easily falls apart. The main premise for social distancing and stay-at-home orders is to safeguard the individual and society at-large from peaks in infection that would overwhelm the nation's healthcare system. Nevertheless, one can imagine a young boy already living with severe asthma who now has to spend all of his day in a dilapidated urban project apartment. After being exposed to mold and secondhand smoke from his neighbors, he too finds himself rushed to a hospital. In this common scenario, society fails to gain the full benefits of stay-at-home orders because the healthcare system is utilized regardless, and those most at-risk for COVID-19 complications are also placed at greater risk of exposure.

Still, as we push for broader pieces of legislation to protect our indoor air, what can that young boy do to potentially mitigate the impacts of harmful indoor air on his health? What can other individuals do to protect themselves and their loved ones during these times of home isolation and beyond? When entering the home, remove shoes at the door to avoid tracking harmful particles inside. If someone in your household has COVID-19 or is a healthcare worker, consider using a highefficiency particulate air (HEPA) purifier in the home. Even though these purifiers are not completely protective against the virus (HEPA filters remove particles of $0.3 \mu \mathrm{m}$ and a coronavirus is $\sim 0.1 \mu \mathrm{m}$ ), they can help remove other pollutants and larger viral/microbiome agglomerates from the air. If it is safe to do so, opening up windows can improve indoor air circulation and dilute indoor contaminants. If cooking, make sure the kitchen remains well-ventilated to avoid harmful exposures to fumes and particulate matter. Finally when cleaning, avoid the overuse of chemicals and air fresheners that may simply be contributing additional hazardous substances to the air. Although there will be limits (e.g., financial, logistical, safety) to the extent to which individuals can fully implement these and similar protective measures in their personal lives, we hope for these suggestions to be a helpful starting place. By continuing to raise awareness - togetherwe can help actualize a future where fewer people succumb to indoor air-related disease.

\section{Compliance with ethical standards}

Conflict of interest The authors declare that they have no conflict of interest.

Publisher's note Springer Nature remains neutral with regard to jurisdictional claims in published maps and institutional affiliations.

\section{References}

1. Brandt EB, Beck AF, Mersha TB. Air pollution, racial disparities and COVID-19 mortality. J Allergy Clin Immunol. 2020. https:// doi.org/10.1016/j.jaci.2020.04.035. 
2. Household air pollution and health. https://www.who.int/newsroom/fact-sheets/detail/household-air-pollution-and-health. Accessed 12 Apr 2020.

3. Cao X, MacNaughton P, Laurent JC, Allen JG. Radon-induced lung cancer deaths may be overestimated due to failure to account for confounding by exposure to diesel engine exhaust in BEIR VI miner studies. PLoS ONE. 2017;12. https://doi.org/10.1371/journal.pone. 0184298.

4. Adamkiewicz G, Zota AR, Fabian MP, Chahine T, Julien R, Spengler JD, et al. Moving environmental justice indoors: understanding structural influences on residential exposure patterns in low-income communities. Am J Public Health. 2011;101:S238-45.

5. Larson A, Bovbjerg V, Luck J. State clean indoor air laws and smoking among adults with poor mental health. J Public Health Policy. 2016;37:453-66.

6. Champion WM, Charley PH, Klein B, Stewart K, Solomon PA, Montoya LD. Perception, culture, and science: a framework to identify in-home heating options to improve indoor air quality in the Navajo Nation. Sci Total Environ. 2017;580:297-306.

7. Tong X, Ho JMW, Li Z, Lui K-H, Kwok TCY, Tsoi KKF, et al. Prediction model for air particulate matter levels in the households of elderly individuals in Hong Kong. Sci Total Environ. 2020; 717:135323.

8. Carvalho Aguiar Melo M, de Sousa Soares D. Impact of social distancing on mental health during the COVID-19 pandemic: An urgent discussion. Int J Soc Psychiatry. 2020. https://doi.org/10. 1177/0020764020927047.

9. Mazza M, Marano G, Lai C, Janiri L, Sani G. Danger in danger: interpersonal violence during COVID-19 quarantine. Psychiatry Res. 2020;289:113046.

10. US EPA O. Introduction to Indoor Air Quality. US EPA. 2014. https://www.epa.gov/indoor-air-quality-iaq/introduction-indoor-a ir-quality. Accessed 23 May 2020.
11. Milner J, Shrubsole C, Das P, Jones B, Ridley I, Chalabi Z, et al. Home energy efficiency and radon related risk of lung cancer: modelling study. BMJ. 2014;348:f7493.

12. Symonds P, Rees D, Daraktchieva Z, McColl N, Bradley J, Hamilton I, et al. Home energy efficiency and radon: An observational study. Indoor Air. 2019;29:854-64.

13. Weschler CJ, Carslaw N. Indoor chemistry. Environ Sci Technol. 2018;52:2419-28.

14. Adams RI, Bateman AC, Bik HM, Meadow JF. Microbiota of the indoor environment: a meta-analysis. Microbiome. 2015; $3: 49$.

15. Leung MHY, Wilkins D, Li EKT, Kong FKF, Lee PKH. Indoor-air microbiome in an urban subway network: diversity and dynamics. Appl Environ Microbiol. 2014;80: 6760-70.

16. Kirjavainen PV, Karvonen AM, Adams RI, Täubel M, Roponen $\mathrm{M}$, Tuoresmäki $\mathrm{P}$, et al. Farm-like indoor microbiota in non-farm homes protects children from asthma development. Nat Med. 2019;25:1089-95.

17. Important EPA Programs Put at Risk by FY2020 Budget Proposal. Environ Prot Netw. https://www.environmentalprotectionnetw ork.org/programs-at-risk/. Accessed 23 May 2020.

18. US EPA O. EPA actions to protect the public from exposure to asbestos. US EPA. 2013. https://www.epa.gov/a sbestos/epa-actions-protect-public-exposure-asbestos. Accessed 15 Apr 2020.

19. ELI's Database of State Indoor Air Quality Laws-Search Page I Environmental Law Institute. 2018. https://www.eli.org/buildings/ indoor-air-quality. Accessed 23 May 2020.

20. Jacobs David E, Tom Kelly, Sobolewski John. Linking public health, housing, and indoor environmental policy: successes and challenges at local and federal agencies in the United States. Environ Health Perspect. 2007;115:976-82. 